\title{
Unfinished Decriminalization: The Impact of Section 19 of the Prostitution Reform Act 2003 on Migrant Sex Workers' Rights and Lives in Aotearoa New Zealand
}

\author{
Calum Bennachie ${ }^{1, *(\mathbb{D}}$, Annah Pickering ${ }^{2}$, Jenny Lee ${ }^{2}$, P. G. Macioti ${ }^{3}$, Nicola Mai ${ }^{4}\left(\mathbb{D}\right.$, Anne E. Fehrenbacher ${ }^{5}$ (D), \\ Calogero Giametta ${ }^{6}{ }^{\mathbb{D}}$, Heidi Hoefinger ${ }^{7}$ and Jennifer Musto ${ }^{8}$
}

Citation: Bennachie, Calum, Annah Pickering, Jenny Lee, P. G. Macioti, Nicola Mai, Anne E. Fehrenbacher, Calogero Giametta, Heidi Hoefinger, and Jennifer Musto. 2021. Unfinished Decriminalization: The Impact of Section 19 of the Prostitution Reform Act 2003 on Migrant Sex Workers' Rights and Lives in Aotearoa New Zealand. Social Sciences 10: 179. https://doi.org/10.3390/socsci10050179

Academic Editor: Nigel Parton

Received: 31 March 2021

Accepted: 13 May 2021

Published: 19 May 2021

Publisher's Note: MDPI stays neutral with regard to jurisdictional claims in published maps and institutional affiliations.

Copyright: (c) 2021 by the authors. Licensee MDPI, Basel, Switzerland. This article is an open access article distributed under the terms and conditions of the Creative Commons Attribution (CC BY) license (https:/ / creativecommons.org/licenses/by/ $4.0 /)$.
1 Department of Criminology and Sociology, Kingston University London, Kingston upon Thames KT1 2EE, UK 2 NZPC-Aotearoa New Zealand Sex Workers' Collective (Auckland Branch), Auckland 1010, New Zealand; auckland@nzpc.org.nz (A.P.); auckland.nzpc@xtra.co.nz (J.L.)

3 Australian Research Centre in Health, Sex and Society, La Trobe University, Melbourne, VIC 3086, Australia; pg.macioti@gmail.com

4 School of Humanities and Social Sciences, University of Newcastle, Newcastle, NSW 2308, Australia; nick.mai@newcastle.edu.au

5 Department of Psychiatry and Biobehavioral Sciences, Semel Institute, University of California, Los Angeles, CA 90095, USA; afehrenbacher@mednet.ucla.edu

6 Department of Sociology, LAMES, Aix-Marseille University, 3007 Marseille, France; calogiame@googlemail.com

7 Faculty of Social Sciences, Division of General Education, Berkeley College, New York, NY 10017, USA; hdh@berkeleycollege.edu

8 Department of Women's and Gender Studies, Wellesley College, Wellesley, MA 02481, USA; jmusto@wellesley.edu

* Correspondence: ofcoursecalumis@gmail.com

Abstract: In 2003, Aotearoa New Zealand (NZ) passed the Prostitution Reform Act 2003 (PRA), which decriminalized sex work for NZ citizens and holders of permanent residency (PR) while excluding migrant sex workers (MSWs) from its protection. This is due to Section 19 (s19) of the PRA, added at the last minute against advice by the Aotearoa New Zealand Sex Workers' Collective (NZPC) as an anti-trafficking clause. Because of $s 19$, migrants on temporary visas found to be working as sex workers are liable to deportation by Immigration New Zealand (INZ). Drawing on original ethnographic and interview data gathered over 24 months of fieldwork, our study finds that migrant sex workers in New Zealand are vulnerable to violence and exploitation, and are too afraid to report these to the police for fear of deportation, corroborating earlier studies and studies completed while we were collecting data.

Keywords: sex work; migrant sex workers; sex workers; migrant sex work; New Zealand; New Zealand Model; sexual humanitarianism

\section{Introduction: Method and Context of This Study}

The data and analyses of this article were conducted in the context of the SEXHUM research project, which explored the relationship between migration, sex work, and trafficking in eight cities within four countries: Australia (Melbourne and Sydney), France (Paris and Marseille), New Zealand (Auckland and Wellington) and the US (NYC and LA) between October 2016 and September 2020. The larger study examines the impact of anti-trafficking initiatives on the governance of migration and sex work. It analyses sex workers' own understandings and experiences of agency and exploitation in order to improve policies and social interventions to address their needs in their own terms. The project aims to study these social dynamics through the theoretical prism of 'sexual humanitarianism', referring to the increasing way in which migrant groups and individuals are understood and targeted as uniquely and specifically vulnerable in relation to their sexual 
behavior, which often legitimizes harmful anti-sex work and anti-immigration initiatives (Mai 2018).

In order to meet its aims, the project hired six postdoctoral researchers for 36 months to undertake long-term fieldwork in each of the four national settings of the project. SEXHUM's research methodology draws upon a combination of qualitative methods: longterm participant observation, semi-structured interviewing, and collaborative ethnographic filmmaking. This methodological approach was adopted to enable the research team to observe and analyze the individual and social dimensions through which sex workers' experience of migration, work, exploitation and trafficking emerge and evolve along the migration process. In each of the 4 national settings, the research set itself the target to undertake 50 semi-structured interviews with cis and trans men and women, as well as with gender non-binary people working in the sex industry. The project also planned to undertake 20 key semi-structured interviews with informants including social service providers, law enforcement, or legal advocates in each site. Between April and July 2020, SEXHUM undertook extra targeted interviews, including repeated ones, focusing on the impact of the COVID-19 pandemic on the lives and rights of migrant sex workers. Overall, the project exceeded its target by undertaking 240 in-depth, semi-structured interviews with purposively sampled sex workers and trafficked persons, and semi-structured interviews with 80 key informants, including social service providers, law enforcement, and legal advocates. Informed consent was obtained from all participants and study procedures were approved by the Institutional Review Boards of Kingston University (UK) and endorsed by key academic organizations in the four national settings of the project (University of Otago in NZ). To protect confidentiality, all interviewees were provided with a pseudonym which was different from their real and work names. Sex workers and trafficked persons were compensated in cash for their time according to national research practices.

The project included Aotearoa ${ }^{1} \mathrm{New}$ Zealand (NZ) as a strategic research site because of the passing of the Prostitution Reform Act (PRA) in (Prostitution Reform Act 2003). The impact of this law on the rights and lives of migrant sex workers is very important for the aims of SEXHUM as the 2003 PRA decriminalized sex work for NZ citizens and permanent residents but excluded migrant sex workers (MSWs) from its protection. Immigration New Zealand (INZ) can deport migrants on temporary visas found to be working as sex workers, which makes them more vulnerable to exploitation. This is the result of the last-minute introduction of Section 19 (s19) of the PRA, against advice by the Aotearoa New Zealand Sex Workers' Collective (NZPC) ${ }^{2}$, as an anti-trafficking clause. During the 2017 election campaign the anti-immigrant commentary from political actors exacerbated these vulnerabilities. The Labour-led Coalition Government that was formed following the election introduced more restrictive migration policies and coincided with an increased focus of INZ against MSWs, who were portrayed either as victims needing rescuing or as a drain on resources by mainstream newspaper articles.

Drawing on original interview and ethnographic data gathered during 24 months of ethnographic fieldwork from March 2017 to February 2019 in Auckland and Wellington, this article will focus on the criminalization of MSWs-both documented and undocumentedin NZ. At the center of our study are both the acknowledgement and the analysis of the enduring role of whiteness and racialization in the implementation of anti-trafficking policies and interventions (Kempadoo 2001; Doezema 2010). These considerations are reflected in the fact that Asian cis women tend to be represented as passive victims and as such targeted by law enforcement and immigration controls (Lam and Lepp 2019; Ham 2017; Dalton and Jung 2019; Hoefinger et al. 2020; Mai et al. 2021) through their explicit and implicit racial profiling in Australia (Selvey et al. 2018; Macioti et al. 2020) New Zealand (Ting 2018; Tichenor 2019) and the US (Cheng and Kim 2014).

To account for the ways in which race, gender and sexuality frame the research process and the realities it investigates, SEXHUM adopted a collaborative intersectional and selfreflexive approach to understand, analyze and address existing inequalities, hierarchies and divisions and relied on post-colonial and decolonial scholars and theories (Jackson 
2020; Mercier 2020). This ethical and methodological approach is particularly important and relevant for SEXHUM because of the whiteness of the research team, which reflects existing privileges in academia and could have potentially discouraged the participation of racialized and marginalized migrants. Being aware of the ways in which racialized inequalities can translate into power disparities during the research process (particularly in interviews), the research team undertook long-term ethnographic fieldwork before undertaking interviews, allowing time for research participants and researchers to establish a relationship of trust, and included the experiences of the widest possible variety of racialized participants from each country setting. Wherever possible, and this was the case in New Zealand, the research team collaborated with racialized community members in project data gathering, co-authored publications with them, and encouraged their participation in dissemination events.

As racialization emerged as a strategic catalyst within the cultural and social processes of sexual humanitarianism, in NZ, we purposely included in our sample a large majority of racialized participants: of the 50 interviews completed in New Zealand (not including the extra ones focusing on the impact of COVID-19), 41 are with People of Color, 30 of them from countries in Asia, with the majority (20) of these 30 participants being of Chinese ethnicity. Two Australian citizens who were born in China were included as interviewees to provide a contrast between migrants who can legally work as sex workers and those who may not and are thus subject to deportation. Furthermore, two refugees were included, both of whom had temporary work permits.

All the interviewees had attended school for at least 13 years, with some going on to tertiary studies of some form, either a University or Technical institute. The age range of interviewees is from 18 to 54 , while the average age at time of interview was 34.04 years. Of the total, 35 identified as female, five as trans women, seven as male, two as non-binary and one as a gender diverse male. This is close to the gender split in sex work in New Zealand found by Abel, Fitzgerald and Brunton (Abel et al. 2007, p. 61). The project also interviewed $20 \mathrm{key}$ informants from government departments and non-governmental organizations, including people of faith, current and former brothel operators, a motelier, and a journalist.

Over the course of the 24 months of collecting data, the lead researcher in NZ spent 50 days in Auckland, five days in Tauranga, and one day in Hamilton. The majority of those interviewed classed themselves as operating independently of brothels, with 26 interviewees doing so, 19 of which were working from their own home or an apartment as a Small Owner-Operated Brothel (SOOB) ${ }^{3}$, and seven working on the street. It was found that most migrant sex workers were on three- or six-month visas, and several of them travelled the country seeking to avoid Immigration New Zealand. Over $470 \mathrm{~h}$ were spent at venues frequented by sex workers, interviewing and taking ethnographic notes. Other than managed brothels and SOOBs, visiting the streets from which sex workers work, and visiting their homes, interviews were also arranged and undertaken at NZPC premises in Auckland and Wellington.

During COVID-19, six extra interviews with sex workers and two with NZPC staff were conducted via video calls by co-author P.G. Macioti, three were with MSWs who had been previously interviewed, and three with new respondents-one (white European) migrant sex worker, one Maori and one white national sex worker-to show the difference in the support available to national sex workers as opposed to migrant ones. We found that the latter were fully excluded from the wide range of support available to all national or PR holding sex workers.

Interviews with sex workers were generally between 60 and $75 \mathrm{~min}$ in duration and each sex worker was provided with NZ\$50 as an incentive for taking part. Interviewees were found through the NZPC, through writing to people through their web-based advertisements, from brothels, and through word of mouth. The interviews were not recorded, but typed responses were checked with interviewees to ensure the responses were what they said. Key informants were recruited by contacting them, or their organization, directly. 


\section{Actions by Immigration New Zealand Affecting the Research}

INZ increased their actions against MSWs following the 2017 election, which culminated in claims they were racially profiling people (Fraser 2018). The Minister of Immigration, concerned about these claims, instructed INZ to cease this practice (Trevett 2018). Between July 2015 and May 2019, INZ refused entry to 481 suspected or known foreign sex workers, while another 43 were stopped from boarding or offloaded from aircraft before leaving their countries for New Zealand with the supposed sexual humanitarian aim of protecting vulnerable women, often coming from Hong Kong, China and Brazil (McCann 2019). Although that covers a three-year period, it is a significant increase on earlier figures, when Lincoln Tan (2013), a New Zealand Herald journalist covering immigration matters, reported "In the 12 months to April [2013], 45 foreigners holding valid working visas were refused entry for breaching their visa conditions, including working as prostitutes".

While migrants in occupations other than sex work are also deported for breach of their visa conditions ${ }^{4}$, sex work is the only occupation prohibited in law, making it specifically illegal for migrants to work in the sex industry in New Zealand, and thus making them liable for deportation solely on the basis of their involvement in sex work. No other occupation is targeted in this way, even where considerable exploitation is documented ${ }^{5}$.

This differential focus on sex work when implementing border controls is mirrored in media representations of bordering processes. Although the TVNZ Channel 1 Border Control program (Greenstone TV 2017) routinely shows people being interviewed at the border for breaches of entry, such as contraband, the only people singled out by occupation were racialized migrants suspected of being sex workers ${ }^{6}$. Furthermore, during early 2018, a series of articles in the New Zealand Herald and on Newshub (Bateman and Hurley 2018; Tan 2018a, 2018b, 2018c) had a negative effect on the public perception of MSWs by making them more visible in sexual humanitarian representations and thereby framing them as target populations.

As a consequence of the convergence between increased INZ interventions and the mediatization of Asian MSWs many were extremely wary about being interviewed. These difficulties are only a small part of the much more significant and negative impact that the convergence between xenophobic political rhetoric, INZ increased interventions on MSWs and their portrayal as sexual humanitarian target victims by mainstream media had on their exploitability and on their access to key health services, which we will discuss below. As a result of the fear caused by these INZ actions, it was difficult for the research team conducting interviews in New Zealand. to reach the initial target of 50 interviews with MSWs (increased to 58 to document the impact of COVID-19).

Although the first 23 interviews were completed between May and December 2017, greater difficulties arose in recruitment after that due to actions by INZ even though some of the authors of this paper are racialized researchers who are also directly involved in delivering key services to, and for, migrant sex workers and who are trusted and well known to their communities. Actions by INZ were sustained throughout the duration of the project, with the media reporting in November 2019 on the deportation of migrant sex workers from the top of the South Island (Gee 2019). The increase in raids by INZ is unsettling for MSWs. It increases their desire to remain hidden and confirms that the criminalization of MSWs through s19 of the PRA makes them vulnerable to abuse, violence and exploitation in NZ in order to avoid deportation, as we will explore below.

In the sections that follow, we are going to analyze our research participants' understanding of the laws framing sex work in NZ, their understandings and experiences of exploitation and trafficking, and the way these dynamics impact their vulnerability to exploitation and their uptake of key health services.

\section{The 2003 PRA Legislation}

In 2003, New Zealand passed the Prostitution Reform Act (PRA). This Act supports the rights, health, and well-being of sex workers, allowing them protections under employment and human rights law that they did not have under the old laws that made their occupation 
illegal. The PRA reformed the laws around sex work by decriminalizing it, removing penalties for soliciting, brothel keeping, procuring, and living on the earnings of a prostitute. The Aims of the PRA are set out in $\mathrm{s} 3$ and are:

“The purpose of this Act is to decriminalise prostitution (while not endorsing or morally sanctioning prostitution or its use) and to create a framework that-

(a) safeguards the human rights of sex workers and protects them from exploitation:

(b) promotes the welfare and occupational health and safety of sex workers:

(c) is conducive to public health:

(d) prohibits the use in prostitution of persons under 18 years of age:

(e) implements certain other related reforms".

The law allows sex workers who are citizens or permanent residents the same rights as all other contract workers. They can complain to organizations that can help them realize those rights. If a brothel operator withholds money from them, sex workers can now, and do, report operators to the Disputes Tribunal (a small claims court that can be used to obtain amounts up to NZ\$30,000 from debtors). NZPC staff state they have witnessed operators repaying money to sex workers, often before the Disputes Tribunal makes a ruling. They also indicate that in every case where a sex worker has turned up for a hearing in the Disputes Tribunal, they have either won, or the case has been settled in their favor before a ruling was made.

Sex workers have also taken operators to the Human Rights Commission (HRC) when subjected to sexual harassment. The Human Rights Review Tribunal (HRRT) ruled that the operator of a brothel must pay the sex worker $\$ 25,000$ for damages due to verbal sexual harassment (DML v Montgomery 2014). More recently, The Director of Human Rights Proceedings, Michael Timmins, announced a six-figure award had been given as a settlement between a brothel and a sex worker who filed sexual harassment proceedings in the HRRT. Settled before the HRRT made a decision, the press release states "the terms of the settlement include payment of a six-figure sum to the woman concerned to compensate her for both emotional harm and lost earnings. The settlement, including the identities of those involved, is otherwise confidential" (Timmins 2020).

It is clear then, that the PRA supports the rights, health, and well-being of sex workers who are citizens or permanent residents. Nevertheless, as mentioned above, s19 of the PRA 2003 (PRA) states that migrants on temporary visas who are found working as sex workers may be deported and are thus excluded from the protections provided by the PRA. Operators of brothels who have PR may also be deported ${ }^{7}$ - only citizens can operate brothels. New Zealand-born sex workers operating in certain towns or cities in breach of the local bylaws may also be classed as working illegally, even if those bylaws are contrary to the PRA, as we will discuss in relation to a specific case below.

\section{Migrant's Understandings and Experiences of Exploitation and Trafficking}

When asked specifically about their experiences of exploitation, research participants did not see themselves as being exploited because they were sex workers, but in relation to specific working conditions and issues such as money and hours worked, whether that was value for money, and also whether brothel operators were withholding money or paying full entitlement. Even though they did not know the details of the PRA, most MSWs, including racialized ones, were generally well aware of their right to say no to any client for whatever reason, and reported using this right often.

Sofia, a 42-year-old Asian cis woman had a significant amount of money held by a brothel operator that should have been sent back to her home country through Western Union. She indicated this was why she no longer worked in managed brothels but worked independently in a SOOB. She felt she could not go through the Disputes Tribunal for fear of deportation:

"The bosses here were not good. The last time a boss stole NZ $\$ 13,000$ from me. They told me they would send it back by Western Union while I was on holiday, but they didn't. They kept it all themselves. They told me I would not be able to 
complain as I would be deported. They eventually gave me back $\$ 7000$ with the help of NZPC and my friends, but there is still $\$ 6000$ that they have not given back. That is also another thing I am here for, to talk to Jenny about that, and how to get it back."

Sofia did not class this withholding of money as exploitation, but theft, although she felt she was unable to do much about it as she was working as a sex worker and thus in danger of being deported. After $\$ 7000$ was returned to her with help from the NZPC, Sofia went back to her country of origin for a short period and later applied for a second visitor's visa to try to get the remaining $\$ 6000$, but also to do sex work. When asked whether she felt that NZ sex work laws protected her, Sophia responded very clearly that she did not think it was the case:

"We can be deported, so not really. People can use that against us, and we can't go to the police if something bad happens, even if not at the shop [brothel]."

Sophia's fear of deportation was shared by the majority of the migrant sex workers we interviewed. Her comment above indicates that the law not only affects migrant sex workers leaving them unprotected and unable to seek justice for wrongdoings in the workplace, but it also leaves them unable to seek justice for "something bad" that happens away from work. Sophia's experience was by no means unique. Other racialized interviewees encountered difficulties in getting the money they were due for services provided back from brothel operators as they felt they could not avail themselves of the Disputes Tribunal for fear of deportation.

Whereas only some research participants faced exploitation in sex work, most of those who had been involved in other work in NZ or had worked overseas, did indicate that they often felt exploited. Interviewees on student and working holiday visas reported the hospitality industry (such as cleaning hotel rooms, restaurant and bar service, and kitchen work) as being exploitative, as the following excerpt from the interview with Sasha, a 32-year-old cis woman from Eastern Europe, clearly indicates:

"It happens a lot in hospo [hospitality industry] - not paying people properly, shifts 10 or $12 \mathrm{~h}$ long, or more, yet not paying properly, only paying for $8 \mathrm{~h}$, not the hours worked. Often people don't know what the rules are and what the laws are around work. So they are underpaying, and often the students or young person won't complain because they don't know about the rules. Call backs, with only $4 \mathrm{~h}$ in between. Employers asking if someone can do a shift, then when asked what time they would finish, the worker is told "I guess you don't need the money then", with the employer expecting you to be available at all times, all the time".

Holders of student visas can only work a maximum of $20 \mathrm{~h}$ per week. Most are employed in the hospitality industry and only earn the minimum wage. Payment rates vary each year, generally by up to $\$ 0.50$, but are often so low that in order to make a living wage, people would need to work over $50 \mathrm{~h}$ per week. Although interview participants reported having been told by people arranging their visas that they would find work easily in NZ, for most this was not the case. Those who did find work, often in hospitality, found that work to be demeaning and not worth the money paid. Some were asked to do extra work, above their $20 \mathrm{~h}$, but were not paid for it. Most did not know what the minimum pay rate was supposed to be in $\mathrm{NZ}^{8}$, were unaware that they could complain, and did not know to whom they could complain if they were not being paid properly.

Joanna, a 27-year-old Asian cis woman, was the only research participant who felt exploited in relation to sex work. She defined her exploitation as having to work longer hours than she wanted to, take clients she felt she would rather refuse and generally lacking control over her life. When we interviewed her in the central city SOOB in Auckland from which she worked, she explained that she initially came to NZ on a visitor's visa (from Australia), which she then changed to a student visa allowing her to work $20 \mathrm{~h}$ in any sector but sex work. Joanna initially worked in a restaurant where she felt exploited because 
she had to do more hours than she was paid for, after which she decided to work as a sex worker. Joanna was very adamant that this was a decision she made herself in relation to the situations she was in and the opportunities available to her:

"We can only work $20 \mathrm{~h}$ a week, yet this not enough money for rent, food. I decided myself to start this work, but after talking with friend and thinking a lot about it. Maybe thinking about it for 2 weeks before actually starting it. ... I came myself. No one force me here to or to do this here except me."

When asked about whether she felt that she was exploited in sex work, Joanna demonstrated that she understood the concept. However, she also explained that it had not related to her situation until she was caught by INZ. In her own words:

Interviewer: "What does exploitation mean for you in your work? How could the situation be improved?"

Joanna: "Not sure of the question, maybe being forced when you not want to? I'm having to force myself to work just now, not because of anyone here, but because of visa stuff."

The 'visa stuff' Joanna mentions refers to an INZ visit to the SOOB she was working at in June 2017, after which she was served a Deportation Liability Notice (DLN) meaning that she had to voluntarily leave New Zealand within 28 days, or face deportation. It is the urgency created by the 28 days DLN timeframe and the need to bring home some money that generated the necessity for Joanna to 'force herself' to work harder, work longer hours, and accept clients she did not want to accept, not the fact of working in sex work per se. In the remainder of the interview, she explained that, while studying, she was seeing no more than five clients a week, she could choose which clients she wanted to see, and if a client got too rough or do things she did not want to do, she would tell them to leave. After the DLN was served upon her, she felt she had to see up to 30 clients a week and work a minimum of $30 \mathrm{~h}$ per week. This stressful situation had a very negative impact on her physical and mental health:

"Makes heart feel bad, period cramps when I not had before, feel shame, feel bad all over. Not able to sleep properly."

Joanna felt forced to sell sex by the circumstances produced by the DLN not unlike a victim of trafficking. However, she clearly did not consider herself or any of her colleagues as trafficked on the basis of an understanding of trafficking that reflects the main dimensions of the definition set by the 2000 UN Palermo Protocol to Prevent, Suppress, and Punish Trafficking in Persons, especially Women and Children ${ }^{9}$.

Interviewer: "What does 'trafficking' mean for you? Can you give me a definition?"

Joanna: "Some people want to earn money from a lady, and force her to work against her will, make her change countries. When I was very young - they tell us in school in Thailand. It's also in newspapers, and on TV in Thailand, and airports, all the time. ( . . ) The ladies just want to earn money. No idea. For me, no. For these other ladies here, no. I think most just do it. I think they only want to earn money for themselves."

Joanna's understanding of trafficking and of herself as a non-victim is representative of the majority of research participants, who had clear ideas about what the concept refers to, as the following quote from the interview with Sasha, a 32-year-old cis woman from Eastern Europe, also shows:

Interviewer: "Do you feel that you have been trafficked?"

Sasha: “No. I did my research, I spoke with people before starting, I wasn't forced, except for the fact I needed money, but we all need money so we could all say we are forced to work, but I wasn't forced to do this job. I wasn't coerced, I wasn't forced. I wasn't detained or sent somewhere by anyone, I wasn't misled 
or told lies about what this job is about. I chose this job, nobody made me do this".

Although one or two had difficulty putting a meaning into words, most defined trafficking as:

- Moving between places (countries, states);

- Without the person's consent or knowledge, or through use of fraud; and

- $\quad$ Being forced to do work they did not want to do, such as sex work, but not limited to sex work.

Some added that it could be between cities in the same country. Most said that they had heard about this when they were quite young, either through school or through the media, as was the case with Joanna. When asked whether the trope-that most migrant sex workers are trafficked-is true, overwhelmingly, they said that it was not true. A few said that perhaps it may be true for a small number of people, but they had never heard of them, or did not know them. A larger number agreed that it would only be true for places other than New Zealand.

The experiences of MSWs who participated in our study do not support media claims that sex workers are victims in need of rescue (Tan 2018a) and confirm existing research showing that there have been no cases of trafficking in NZ (Prostitution Law Review Committee 2008; Roguski 2013; Armstrong 2018). The only victims of trafficking we interviewed in the context of the project were two white Kiwi young men who had just turned 18 and had been working as sex workers prior to attaining that age. As people who were working as sex workers under 18, they are legally classified as victims of trafficking. However, even these young people rejected the imposed label of trafficking victim by emphasizing that they were not forced to sell sex by anyone and did not do anything that they did not want to do.

When appraising the extent of exploitation and trafficking in sex work in NZ, it is important to note that the emphasis within the anti-trafficking discourse on extreme cases of sex work exploitation means that more 'mundane forms of exploitation' experienced by sex workers might be overlooked as a result (Armstrong 2018, p. 87). Our data and findings acknowledge this danger while also taking into consideration the parallel danger that in the absence of any definition of what constitutes exploitation in international law this can be framed and addressed according to the sensibilities of people in positions of power and not of those directly concerned, which often results in attempts to abolish livelihood strategies on which depend marginalized populations such as sex workers and child laborers (Howard 2020).

These concerns are particularly relevant for the study of migrant sex work. The fact that that the definition of trafficking contained in the 2000 UN Palermo is informed by a neo-abolitionist sensibility (Ditmore and Wijers 2003) and lacks a clear definition of exploitation allows a considerable degree of arbitrary discretion, which often translates into repressive anti-migrant and anti-sex-work interventions and policies in the name of the fight against trafficking (O'Connell Davidson 2005, p. 73; Fehrenbacher et al. 2020; Musto et al. 2021). A typical example is London Metropolitan Police anti-trafficking Operation Lanhydrock on 20 October 2016, which targeted six massage parlors in Soho and Chinatown in Central London and resulted in seven arrests for "controlling prostitution for gain," while seventeen sex workers were arrested for breaking immigration law and detained by the UK Border Agency (Mai 2018, p. 114). The results of the SEXHUM project show clearly that humanitarian policies against trafficking tend to legitimize increasingly repressive interventions against sex work and 'extreme bordering' measures against migration (Mai et al. 2021). In the next section of this article, we will focus specifically on the ways these broader trends were reflected in New Zealand by focusing on the impact of s19 of the 2003 PRA Law on the lives and rights of MSWs. 


\section{Impact of s19 of the 2003 PRA Law \\ 5.1. Fear of Deportation}

Nearly all of the women-mostly Asian-who were interviewed stated that if "something bad" happened outside work, such as assault, a car accident, or any other incident where the police should be involved, they would refuse to report the incident to the police because of that fear of deportation despite that incident not being related to their sex work.

The fear of the police finding out about their sex work and reporting them to INZ was certainly the case for Asian cis women Yumi (27 years old) and Sunny (32 years old).

"No, I'm thankful I haven't had any experience with the police. I would not want them knowing what I do. I would not want them to be able to let Immigration know what I do. I want to finish my three months and be able to come back if I want."

"I do not think I would contact the police though if something went wrong, even if it wasn't at work, because I do not want them knowing what I do as I think they may tell Immigration, and I do not want them to know as I may get deported."

Yumi and Sunny's reluctance to contact law enforcement shows clearly the negative impact of s19 on MSWs' safety as most interviewees clearly stated they would not report violence or other crimes against them to the police.

The fear of deportation also affected the actions of MSWs in several ways and sometimes led them to lead very secretive and almost carceral lives, as this excerpt from the interview with Joyce, a 54-year-old Asian cis woman, shows.

"When I work in the motel, I always shut the curtains tightly, so no one can see in and I don't let people know who I am ... I would only leave the motel to go shopping at night, so it was harder for others to see me. As an escort girl, we are very stressed because of the laws. It's very scary to walk along the main road in case we are seen by Police or Immigration. I always put my head down. Then when I sometimes hear the police car, or radio, and I'm always very scared and nervous, in case I am caught by them. And sometimes I get a client who is very rough, they cannot cum, so they get very angry, so it's easier and safer to refund them the money in case they call police. We escort girls who are immigrants are always scared that the person who has PR, they say that they will "call Immigration who will catch you". We always say a migrant escort girl is always suffering because of this. They bully us, but we can't fight back because they can call police or immigration any time and have us thrown out of the country."

Joyce's words were echoed by several interviewees, whose stories and data confirm that the criminalization of MSWs through s19 makes them vulnerable to abuse, violence, sexual assault and exploitation in NZ.

\subsection{Potential for Sexual Violation through Blackmail}

The fear of deportation was not experienced only by women racialized as Asian but by all the people we interviewed who were on temporary visas. For instance, Molly, a 32-year-old European cis woman, was contacted by a person claiming to have friends working for Immigration New Zealand, who demanded free services from her or he would arrange her deportation. In fear of being deported, she acquiesced to sexual conduct. In respect of this, Molly stated:

"The first time something bad happened here, I was in H., and this guy said he had the images from my web advert, and that I was working illegally from a hotel in H. Apparently, they have a bylaw there that says you can't work in hotels or motels ${ }^{10}$, but most private people do if they are touring. At the time I had a face pic on my advert, so that came off pretty quickly. He said he had friends working in Immigration and would tell them what I did and give them my images, and advert, if I didn't do what he told me. I was too shocked, freaked right out, at the 
time to think properly, so I just did it, and afterwards I was too scared to go to the police to report it, just in case I did get deported or even charged under that bylaw".

Sections 128A and 129A of the Crimes Act 1961 state that acquiescing to sexual conduct is not consent and is thus sexual violation-rape. Similarly, because of fear of being deported, she would not report this case to the police. This was not the only time Molly was threatened, as the following excerpt from her interview shows:

"I was in a motel in N., and I'd just had a client, then I also had another client text me, as my advert says text only, but because I'd just had a client, and wanted some time to relax, I said no. The next text he's saying I'm in room such and such, describing me. He must have seen me in reception and been there at the same time, so he was probably in the same hotel. It was really creepy. I told him my mother was a kiwi and I was travelling on a kiwi passport. I'm just glad I was able to think quick enough to say that. I checked out the next morning and went somewhere else."

Being of European ancestry, Molly could use this excuse. Nevertheless, this blackmail happening twice to her indicates how widespread such threats must be. Migrant workers are too afraid to report incidents such as this to the police and those who commit them are therefore able to avoid penalty. It also shows the discriminatory impact of s19 of the PRA, as Molly, a person of European ancestry, could escape a potentially abusive client by pretending to be a NZ citizen, while racialized migrants would be unlikely to be believed, even if it were true.

Joyce, a 54-year-old Asian cis woman, was raped in a motel and found by the cleaner and motel owner. She told them not to contact the police, who was informed by the owner anyway.

"The motel owner and housekeeping, they cut all the tape off my body, and they wanted to call the police. I begged them not to, as I was not a resident."

She rang a friend who came to her motel, and she used her phone to call another friend in C. to pick her up. The two of them travelled back to $C$. driven by the friend from there. Halfway there, Joyce's friend's phone rang, and she realized it was the police. Joyce told them that she did not want to speak to them. In C. the next morning, Joyce received a call from her friend who had travelled back with them saying the police were at R. looking for her. Joyce went to R., believing that her friend, who was now in the police car, had been arrested.

"One of my other friends called and said there were a lot of police in R. as they had found my friend who lent me her phone. That friend asked me to come out to R. She said the police said they wanted to find me to help me ... My friends said I must come out to R., explain all this, and I said "Yes, I go out and surrender". I ask my friend to take me to one hotel, but then also took a taxi to the R. one. Already my friend from B. was in the police car. I asked the taxi driver to carry my luggage down, and I told the Police I come to surrender. I spoke to a lady police officer, and she tell me she want to help me and ask why I brought my luggage. I said "You catch my friend, I come to surrender". The lady police officer tell me to come to police car, and we talk in car, and I told them to let my friend go before I get in the police car."

Joyce eventually agreed to give a statement to the police but felt coerced into doing so by the circumstances mentioned above. Moreover, because of the fear of being involved with the police, she was later abandoned by her friends:

"I tried to find my friend at the shop [brothel], but she no longer wanted to be my friend as I have police phone and police will be able to trace it and find where the call is going to. ( . . ) I said I never told the police anything about them, but the police had only helped me see a doctor for treatment. My friends told everyone else not to get involved with this (omitted as potentially leading to identification) 
girl as she has gone to the police and has a police phone. They didn't understand about what had happened, and they still think Police are not good."

The fear of deportation potentially resulting from police intervention eventually left Joyce without a support system around her. Luckily police informed her about the NZPC who were able to support her and provide the help she needed. The person who raped her was eventually arrested, convicted and sentenced to jail (Eder 2019) and Joyce voluntarily returned to her country of origin just after the trial was concluded. However, shortly thereafter, INZ began deporting MSWs in the region around the town in which she was raped, supported by local police (Gee 2019). Such actions by the police, so soon after assisting a person to convict their rapist, can be seen as corroborating MSWs fears that if they seek help from the police, it will lead to them, or their friends, being deported.

The comparison between the experiences of Molly and Joyce highlights the racialized uses and impact of s19, as well as its clearly negative and discriminatory impact on the lives and rights of all migrant sex workers. Our research data refute political claims that s19 protects migrant sex workers from trafficking and harm. For instance, Iain Lees-Galloway, Minister of Immigration from October 2017 to July 2020, defended the section by stating that the

"... view remains that actually if you say that sex work is open to migrant workers that actually creates an incentive to traffic people to New Zealand. And, and, and I can say, from our point of view, it is working well to achieve the outcomes that were intended with that legislation. It is focused on harm reduction, and we have next to no evidence of trafficking of people to New Zealand to work in the sex industry ... " (Radio New Zealand 2020, time 2:563:29).

Based on evidence gathered with migrant sex workers in New Zealand our findings show that they are extremely reluctant to report violence against them to the police or to seek medical treatment before their life is endangered. They also highlight the racialized uses of the law, which impact more negatively on the lives and rights of persons of color. Altogether, these dynamics clearly indicate that s19 of the PRA is actually not "working well" in terms of reducing the harms that can be associated with migrant sex work.

\subsection{Inappropriate Policing Procedures}

The cases of sexual violation analyzed above are among the most extreme, but not the only examples we encountered of the ways in which the criminalization of MSWs in NZ generates the conditions for abuse and violence on the part of both criminals and law enforcement. For instance, one of the cis Asian women who were served a DLN, was interrogated, naked, by a male police officer at the brothel she was working. She was about to have her photos taken for their website, which is why she was naked. Although the police officer interviewing her allowed her to put a coat on before interviewing her and interviewed her in Mandarin, he wrote his report in English and asked her to sign it even though she could not read it because her command of English at the time was limited. It is concerning that male police officers interviewed her while she was wearing only a coat, not allowing her to get fully dressed and that they encouraged someone who had little understanding of English to sign a document written in English. The three Chinese interpreters with whom we discussed this case highlighted that most Chinese workers would always do what the police said for fear of repercussions, based on their experiences of law enforcement in China, which means that Chinese migrant sex workers are therefore unaware of the rights they have when questioned by the police in New Zealand.

Two of the other interviewees who were given a DLN had Immigration New Zealand officers respond to their advert online. Immigration New Zealand officers made an appointment as if they were clients in order to enter commercial sex premises. In both cases, male Immigration New Zealand officers had identified MSWs using images on the internet, showing their bodies in varying states of dress, but only used the images in which they were naked during the interrogation. In one case, there was only one image of the sex 
worker naked among the 15 or so images of her on the brothel webpage. The research participant in question, a 22-year-old Asian cis woman, found the use of a naked image of her intimidating and embarrassing. In her own words:

"He used photos taken from the work website, photos of me naked, which was not good."

In both of these two cases, Immigration New Zealand officers would ask the same question time after time. "Is this you", "we know you're working, how long have you been working here", "what do you do here", and "why are you here" are the most common questions. The second person who had been given a DLN broke down while talking about this during the interview with us, which prompted us to terminate it in order to minimize her discomfort. The following excerpt from the interview with INZ's Assistant General Manager of Border Operations shows that using a naked picture to identify a MSW is justified as congruent to the task of proving that a person is involved in providing sexual services:

Interviewer: "How appropriate do you think it is for a male Immigration Officer to be using a naked image of a sex worker, when there are ones of her dressed, from the same website, or should it have been the female Immigration Officer interviewing her?"

Assistant General Manager, Border Operations: "Those ones are going to be used evidentially, to support a DLN, or support a case for deportation. The naked ones comes down to us being in an invidious position of having to prove, that, on balance, this person is involved in providing sexual services. Therein lies the whole difficulty. I don't like my staff being put in that position ... Yes! Undoubtedly [they should be interviewed by a woman], and, that's certainly acknowledged."

Although some responsibility is acknowledged for having a male officer, rather than a female officer, interview a half-naked woman, the cases presented above were by no means the only testimonies of inappropriate questioning our research participants informed us about. Overall, they also reveal the climate of racialized intimidation during INZ interventions that is made possible by s19 of the PRA.

\subsection{Health Concerns}

Access to health is also negatively affected by s19 of the PRA. While most migrant sex workers reported they believed they could go to a doctor, or seek medical attention, they were loath to let that person, a doctor or a nurse, know that they were doing sex work. This reluctance was shared by all research participants and not only by those racialized as Asian, as this excerpt from the interview with Sasha, a 32-year-old cis woman from Eastern Europe, shows:

"I am worried about seeing doctors-worried about being found out. I have only been to NZPC and Wellington Sexual Health for check-ups. I have tourist insurance, travel insurance, so I can go to other clinics, but I would never reveal any sex work involvement in case I was deported. I don't think I would go to the police either, if someone was violent against me while I was at work, or committed some other crime against me while I was at work, in case the police reported it to immigration and I was deported. So yes, these two things, they maybe have some impact on my health."

It should be noted that medical staff in New Zealand are forbidden from letting third parties know about patients and may only let the police know about patients when they may be a danger to themselves or to others. Most MSWs interviewed seemed not be aware of this and feared letting a doctor (including sexual health doctors) know what they did, which sometimes had very negative effects on their health.

Rather than seeking health assistance in NZ, the majority of people of Chinese ethnicity stated they would not seek medical assistance in New Zealand, but would return to China for treatment, even for a fairly minor condition, rather than risk doctors telling Immigration 
New Zealand about their occupation, as the excerpt from the interview with Anna, a 21year-old cis woman, shows:

"I will be going back to China soon as my parents will meet me, so I won't need to do any medical stuff here. I will do it all back in China."

The most severe case of the negative impact that s19 of the PRA 2003 has on the health of MSWs was that of Lia, a 33-year-old cis woman from Latin America, who had been ill for a week but only approached a nurse at the NZPC when she had five days left in NZ and with a severe temperature of over $40^{\circ} \mathrm{C}$. The nurse told her she was not able to treat her as her elevated temperature required treatment she could not provide and sent her to the After-Hours Medical Centre. They, too, were not able to provide the treatment she needed, so she was sent to the Emergency Department at the hospital. In her fevered state, she destroyed anything that could link her to sex work and put it in a bin in a different cubicle. In her own words:

"I went to the nurse at NZPC first, but she told me not an STI, but concerned about how hot I was, so I went to ... Emergency Clinic [After Hours Clinic] for prescription, but also they were really concerned about me, and sent me to the hospital for ED [Emergency Department], they wanted me to stay for the morning, but I was worried about cost, and so I left after they said my temperature had started to come down. Also when there, I had the information sheet about this interview in my bag from NZPC, so I took it out and (demonstrated ripping it up) and threw it in the bin. Not the bin beside me, but someone else. I didn't want them to find out I was doing this job as I might get into trouble with Immigration."

Lia's case shows the depth to which the fear of being deported goes, which overrode the concern for her health to the point of risking her own life. Before being discharged, she was told she was lucky she had not gone into a coma because of her elevated temperature, which could have led to her death.

The cases reviewed in this section show once more the paradoxical situation MSWs find in NZ, where they are reluctant to access confidential and vital health services available to them thanks to a decriminalized environment that also excludes them from the protections granted by the PRA. This paradoxical situation is exemplified best by the fact that despite the difficulties they encountered because of s19, most migrant sex workers reported that their health in New Zealand doing sex work was better than it was in their home country. Nearly all reported better mental health and increases in self-confidence and self-esteem. Even those who had been served a DLN said that until they were given that, or before Immigration New Zealand arrived, their lives were much better and their health was much better than previously.

\section{Conclusions: Unfinished Decriminalization}

Overall, our findings highlight the fundamental, positive contribution that decriminalization made to the lives and rights of sex workers in New Zealand. The PRA, as currently written, provides NZ born and those who have acquired PR or citizenship with a variety of protections, including the ability to lodge complaints to the Human Rights Commission, the Disputes Tribunal, the police, and labor authorities without fear of any form of retribution from another arm of the State. Their rights are protected by the PRA.

These observations are corroborated by the fact that all research participants were against the introduction of any law criminalizing clients according to policies similar to the Swedish model: a neo-abolitionist approach framing sex work as violence against women, and aiming to abolish it by decriminalizing sex workers and criminalizing clients to 'end the demand' for sexual services. When asked what they thought about this policy framework research participants said that there would only be bad clients left, and that, needing money, they would not be able to refuse these bad clients. As a result of this, the research participants said that violence would increase. They were also concerned that 
clients would use the law as an excuse not to pay them. More than one research participant specifically said, "I have to get paid".

Because of s19 for migrant sex workers on temporary visas, the situation that occurred prior to the passage of the PRA remains. The experiences of migrant sex workers gathered in the context of the SEXHUM project (and discussions with NZPC staff during ethnographic visits to community bases in Auckland and Wellington) and analysed in this article demonstrate clearly that cases of violence do occur and that migrant sex workers who are victims of rape and other violence are too scared to report the incidents to the police for fear of deportation. In this respect, our research data and findings corroborate and build upon the evidence produced by previous studies. Gillian Abel and Michael Roguski (Abel and Roguski 2018, p. 9), in a report prepared specifically for Immigration New Zealand, found that MSWs were vulnerable to violence because of s19 PRA. Armstrong (2018) and Ting (2018) also found that MSWs were vulnerable and feared deportation. It should be noted that according to Ting (Ting 2018, p. 94), MSWs "viewed deportation as a greater risk than violence."

Our findings show that MSWs in NZ are targeted by sexual humanitarian antitrafficking law enforcement initiatives, including undercover police activities, acting as 'extreme bordering' practices (Mai et al. 2021) and exacerbating sex workers' vulnerability to exploitation, violence, and physical and mental health issues. As a result of this, crimes such as sexual violation and sexual assault are not reported to the police, and the people committing such crimes are not punished, encouraging them to think they can continue to do so. Migrant sex workers are also afraid to let doctors know what they do and do not seek help even when their lives are at stake for fear of being deported. This has grave implications for the health of both migrant sex workers and their clients, which is very significant given that the PRA 2003 was passed on public health grounds.

The experiences analyzed in the article also highlight that s19 of the PRA 2003 can be used to exploit sex workers, and acts as a Blackmailers Charter (British Library n.d.) allowing those who commit sexual or other violence against MSWs to potentially walk free. They also show that the intimidating techniques deployed by INZ and the police exacerbate the already existing reluctance to report crime for fear of being deported. As a result, people who sexually assault or sexually violate sex workers can do so repeatedly without fear of the law because they know that migrant sex workers are unwilling to report crimes against them for fear of deportation.

Our overall data and findings highlight the unfinished nature of the process of decriminalization in New Zealand, which needs to include MSWs regardless of their visa status, in order not to reproduce racialized and sex-gendered borders putting migrant workers at heightened risk of exploitation, violence and criminalization and limiting their access to safety, justice, and health. They also corroborate studies suggesting that antitrafficking interventions should separate themselves from anti migration and anti sex work law enforcement if they want to reduce the vulnerability to exploitation of the people they aim to support (Segrave et al. 2009, p. 202).

SEXHUM findings in NZ strongly support the conclusions of the United Nations Committee for the Elimination of Discrimination Against Women (CEDAW), which in 2018 stated that "migrant women engaged in prostitution may be exposed to exploitation and are at risk of trafficking, owing to the ban on engaging in prostitution imposed on migrants, which prevents them from reporting abuse for fear of deportation". As a result, the CEDAW Committee recommended that s19 of the PRA be amended, "with a view to reducing its negative impact on migrant women" and "adopt measures aimed at preventing discrimination against women in prostitution in the State party, with a view to preventing and addressing the factors and structures that render migrant women vulnerable to trafficking" (United Nations 2018, CEDAW/C/NZL/CO/8, paras 27(a), 28(a) and (b), 2018, pp. 8-9).

As Macioti et al. recently documented, in New South Wales Australia, where migrant sex workers are included in the state's 1995 decriminalization of sex work and access to 
work visas recently became easier for sections of the migrant population, trafficking in the sex industry decreased dramatically and migrant sex workers are considerably less bound to exploitative bosses (Macioti et al. 2020). Indeed, our overall global findings indicate that, given the scale of involvement of migrant sex workers in sex work worldwide, any policy and social intervention on sex work can only have a chance of succeeding if it also includes prospective and actual migrants' legal right to access the international labor market, which would reduce their exploitability by the people who facilitate their labor migration (Bravo 2009). In NZ this means that in order to address the needs of migrant sex workers the repealing of s19 of the PRA is a necessary but not sufficient priority. This measure alone would be insufficient to tackle their vulnerability to exploitation and abuse, which would be reduced further by also separating immigration controls from the enforcement of the PRA, by removing the ban on contract employment for people on temporary visas, and by eliminating the requirement to tie work visas to a particular employer.

The institution of a work visa that people can apply for if they start work as a sex worker could also be helpful as it would allow prospective migrants to avoid potentially exploitative intermediaries and employers by being able to hold a legal visa. These visas must not be tied to a specific sex work venue to ensure that if the sex worker feels unsafe in that venue, they can move to another without having to reapply for a visa. MSWs found in breach of their visa for working as sex workers should be encouraged to apply for that visa rather than being served an immediate DLN. It is also important, however, to ensure that this visa should not be specific to sex work or name sex work explicitly in order to reduce any restrictions on travel to other countries and decrease or avoid stigmatization and abuse for prospective and actual MSWs in their countries of origins. Implementing these measures would uphold the recommendations from the CEDAW Committee (CEDAW/C/NZL/CO/8) and reduce the vulnerability of MSWs to exploitation and abuse by enabling them to report violence to the authorities, to seek medical attention, and to access the rights allowed by the law, in the same way that it is possible for sex workers who are permanent residents or citizens of New Zealand.

Author Contributions: C.B. wrote the first draft of this article. C.B., A.P., J.L., P.G.M. and N.M. conceived of, planned, and conducted the interviews and ethnographic data collection for this paper in New Zealand. C.B., A.P., J.L., P.G.M., N.M., contributed to the theoretical and methodological framing of the article and edited its final version; A.E.F., C.G., H.H. and J.M. edited its final version; N.M. led the SEXHUM project and secured all funding for it. All authors have read and agreed to the published version of the manuscript.

Funding: This study was supported by the SEXHUM (Sexual Humanitarianism: understanding agency and exploitation in the global sex industry) Consolidator Grant from the European Research Council (ERC CoG 682451). More information about the SEXHUM project is available in its website: www.sexhum.org (accessed on 1 May 2021). Support for Dr. Fehrenbacher was also provided by a center grant at the UCLA Center for HIV Identification, Prevention, and Treatment Services (NIMH MH058107), a training grant at the UCLA Semel Institute for Neuroscience and Human Behavior (NIMH T32MH109205), and a training grant at the University of California Global Health Institute (UCGHI) from the NIH Fogarty International Center (FIC D43TW009343). The content is solely the responsibility of the authors and does not necessarily represent the official views of the ERC, NIH, FIC, or other funders.

Institutional Review Board Statement: The study procedures were approved by the Institutional Review Boards of Kingston University in London and the University of Otago in New Zealand.

Informed Consent Statement: Informed consent was obtained from all subjects involved in the study.

Data Availability Statement: Due to confidentiality protections for study participants required by the Institutional Review Boards that approved this study, the data cannot be made publicly available.

Acknowledgments: We would like to thank all of our study participants, community partners, and advisory board members for contributing their time and insights and for supporting the project.

Conflicts of Interest: The authors declare no conflict of interest. 


\section{Notes}

1 Aotearoa is the indigenous Maori name for New Zealand, and means Land of the Long White Cloud.

2 Our interview with Catherine Healy, the founder and National coordinator of Aotearoa New Zealand Sex Workers' Collective (NZPC) shows that the section that was to become s19 of the PRA was added against the advice of the NZPC and the then Minister of Immigration, Lianne Dalziel would not discuss the matter with the NZPC, who had highlighted the vulnerability of both street sex workers and migrant sex workers if they were excluded from the protections offered by the PRA.

3 A Small Owner-Operated Brothel (SOOB) is a place where a sex worker can operate independently by themselves or with up to 3 others so long as no one person is in charge, and all manage their own sex work. The New Zealand model requires operators to have operator's certificates, even if in charge of only one sex worker. Sex workers in charge of their own sex work while working in a SOOB of 4 or less people do not need to apply for an operator's certificate. If one person was in charge, it would cease to be a SOOB and that person would require an Operator's Certificate. S19 of the PRA states that any person on a temporary visa or a permanent resident may not be a brothel operator, and if caught faces deportation.

4 In KZ (Skilled Migrant) v Benson [2020] NZIPT 205601 (21 January 2020): Immigration New Zealand declined KZ's residence application because it considered that her offer of employment as a graphic designer was not genuine as: (a) the employer offered a substantial increase in pay without adequate explanation. (b) the employer kept the job offer open for an extended time. (c) KZ did not apply for a work visa, and (d) KZ did not demonstrate she had an offer of full-time employment. It was not because of her type of employment, but because of other reasons she was declined. This contrasts with MSWs who are deported solely because of their involvement in sex work.

5 Hospitality continues to be an accepted occupation for migrants despite a significant number of employment cases showing a large amount of exploitation within the sector, i.e., Gate Gourmet New Zealand Limited v Sandhu [2020] NZEmpC 237 (21 December 2020) http:/ / www.nzlii.org/cgi-bin/sinodisp/nz/cases/NZEmpC/2020/237.html last accessed 1 May 2021; Labour Inspector of the Ministry of Business, Innovation and Employment v Shah Enterprise NZ Limited [2020] NZERA 505 (7 December 2020) http:/ / www.nzlii.org/cgi-bin/sinodisp/nz/cases/NZERA/2020 /505.html last accessed 1 May 2021. These are two examples from December 2020 alone.

6 Episode 1 of Series 9 (broadcast on 20 June 2017) shows a young Brazilian woman being questioned by customs, who find condoms, lube and a sex toy in her possession, assume she is a sex worker and apply pressure through questions before handing her over to an INZ agent who obtains a confession. During the introduction to the programme, there is a short clip from her interview with customs where she is asked "for a 30-min massage, how much money do you charge?" Although others are also in the introduction, the questions shown regard contraband-food, alcohol, and cigarettes-rather than occupational questions. The other group identified by occupation is a group of Ukrainian fishermen. However, they are not questioned because of their occupation, but because they arrived on a charter flight and in relation to contraband cigarettes and alcohol, which were found on one of the fishermen. An elderly Asian couple are also pulled aside on camera, but this is because they indicated they had food in their luggage, not because of their occupation-suspected or real.

7 When the PRA was passed, people on Permanent Residency Visas could operate brothels. The change to exclude them was made in 2010 following an amendment to the (Immigration Act 2009).

8 There are 3 types of minimum wage in NZ-adult, starting-out and training. The adult minimum wage is currently NZ\$18.90 an hour before tax if you're 16 years or older. The minimum wage increases once a year. During the course of this study, the minimum wage varied from NZ\$15.75ph in April 2017 to NZ\$17.70ph https:/ / www.employment. govt.nz/hours-and-wages/pay/minimum-wage/minimum-wage-rates/ last accessed 1 May 2021.

9 According to the 2000 UN Protocol to Prevent, Suppress and Punish Trafficking in Persons Especially Women and Children which was signed in Palermo, Italy, in 2000 'trafficking in persons shall mean the recruitment, transportation, transfer, harbouring or receipt of persons, by means of the threat or use of force or other forms of coercion, of abduction, of fraud, of deception, of the abuse of power or of a position of vulnerability or of the giving or receiving of payments or benefits to achieve the consent of a person having control over another person, for the purpose of exploitation'.

10 This city has one of the most restrictive bylaws in New Zealand. Sex work may only take place within a specific area, an area that has shrunk with each review of the bylaw. Despite no street-based sex work occurring they stated in the bylaw that street-based sex work was not allowed. The bylaw also states that sex work may not take place in a hotel or motel "unless the agreement occurred elsewhere". Breaches of the bylaw incur a fine of up to NZ\$20,000. 


\section{Case Law}

DML v Montgmery [2014] NZHRRT 6 (12 February 2014). Available online: http:/ /www.nzlii.org/nz/cases/NZHRRT/2014/6.html (last accessed on 3 March 2021).

JS (India) [2020] NZIPT 505052 (23 October 2020). Available online: http:/ /www.nzlii.org/nz/cases/NZIPT/2020/505052.html (last accessed on 3 March 2021).

KZ (Skilled Migrant) v Benson [2020] NZIPT 205601 (21 January 2020). Available online: http:/ /www.nzlii.org/nz/cases/NZIPT/2020 /205601.html (last accessed on 3 March 2021).

\section{References}

Abel, Gillian, and Michael Roguski. 2018. Migrant Sex Workers in New Zealand: Report for the Ministry of Business, Innovation and Employment. Christchurch, (NZ): University of Otago. Available online: https://www.nzpc.org.nz//pdfs/Abel,-G-and-Roguski, -M,-(2018),-Migrant-sex-workers-in-NZ-report-for-MBIE.pdf (accessed on 3 March 2021).

Abel, Gillian, Lisa Fitzgerald, and Cheryl Brunton. 2007. The Impact of the Prostitution Reform Act on the Health and Safety Practices of Sex Workers: Report to the Prostitution Law Review Committee. Christchurch: Otago University. Available online: http://www.otago.ac. nz/christchurch/otago018607.pdf (accessed on 3 March 2021).

Armstrong, Lynzi. 2018. New Zealand. In Global Alliance Against the Trafficking of Women. Edited by Sex Workers Organising for Change: Self-Representation, Community Mobilisation and Working Conditions. Bangkok: GAATW International Secretariat. Available online: http:/ / www.gaatw.org/publications/SWorganising/SWorganising-complete-web.pdf (accessed on 3 March 2021).

Bateman, Sophie, and Emma Hurley. 2018. Immigration Admits Underreporting Migrant Sex Work Complaints, Newshub. May 1. Available online: https:/ /www.newshub.co.nz/home/new-zealand/2018/05/immigration-admits-underreporting-migrant-sexwork-complaints.html (accessed on 3 March 2021).

Bravo, Karen E. 2009. Free Labor! A Labor Liberalization Solution to Modern Trafficking in Humans. Transnational Law and Contemporary Problems 18: 545-16. Available online: https://scholarworks.iupui.edu/bitstream/handle/1805/24119/Free\%20Labor\%20A\%20 Labor\%20Liberalization\%20Solution\%20to\%20Modern\%20Trafficking\%20in\%20Humans.pdf?sequence=1 (accessed on 1 May 2021).

British Library. n.d. The Criminal Law Amendment Act 1885. In Collection Items. London: British Library. Available online: https:/ / www.bl.uk/collection-items/the-criminal-law-amendment-act-1885 (accessed on 3 March 2021).

Cheng, Sealing, and Eunjung Kim. 2014. The paradoxes of neoliberalism: Migrant Korean sex workers in the United States and 'sex trafficking'. Social Politics 21: 355-81. Available online: https://academic.oup.com/sp/article-abstract/21/3/355/2259017 (accessed on 1 May 2021). [CrossRef]

Dalton, Bronwyn, and Kyungja Jung. 2019. Becoming cosmopolitan women while negotiating structurally limited choices: The case of Korean migrant sex workers in Australia. Organization 26: 355-370. Available online: https://journals.sagepub.com/doi/10.117 7/1350508418812554 (accessed on 3 March 2021). [CrossRef]

Ditmore, Melissa, and Marjan Wijers. 2003. The negotiations on the UN protocol on trafficking in persons. Nemesis 4: 79-88. Available online: https: / / lastradainternational.org/lsidocs /6\%20The \%20negotiations \%20on \%20the\%20UN\%20Protocol\%20(NEMESIS) .pdf (accessed on 3 March 2021).

Doezema, Jo. 2010. Who Gets to Choose? Coercion, Consent, and the UN Trafficking Protocol, Gender and Development. 2002, Vol. 10, Issue 1: Trafficking and Slavery. Available online: https://www.tandfonline.com/doi/abs/10.1080/13552070215897 (accessed on 1 May 2021).

Eder, Jennifer. 2019. Escort Abducted and Raped in Blenheim Motel Room, Stuff.co.nz. September 17. Available online: https: //www.stuff.co.nz/national/crime/115847312/escort-abducted-and-raped-in-blenheim-motel-room (accessed on 3 March 2021).

Fehrenbacher, Anne E., Jennifer Musto, Heidi Hoefinger, Nicola Mai, P. G. Macioti, Calogero Giametta, and Calum Bennachie. 2020. Transgender people and human trafficking: intersectional exclusion of transgender migrants and people of color from antitrafficking protection in the United States. Journal of Human Trafficking 6: 182-194. Available online: https: / / www.tandfonline. com/doi/abs/10.1080/23322705.2020.1690116?journalCode=uhmt20 (accessed on 3 March 2021). [CrossRef]

Fraser, Cleo. 2018. Immigration NZ Accused of Racial Profiling after Data Pilot Program Unearthed, Newshub. April 5. Available online: https:/ / www.newshub.co.nz/home/new-zealand/2018/04/immigration-nz-accused-of-racial-profiling-after-datapilot-program-unearthed.html (accessed on 3 March 2021).

Gee, Samantha. 2019. Migrant Workers in Top of the South Deported, Stuff.co.nz. November 11. Available online: https://www.stuff. co.nz/national/crime/117188869/migrant-sex-workers-in-top-of-the-south-deported (accessed on 3 March 2021).

Greenstone TV. 2017. Border Control, TVNZ. June 20. Available online: https://www.tvnz.co.nz/shows/border-patrol/episodes/s9-e1 (accessed on 3 March 2021).

Ham, Julie. 2017. Sex Work, Immigration and Social Difference. London: Routledge. 
Hoefinger, Heidi, Jennifer Musto, P. G. Macioti, Anne E. Fehrenbacher, Nicola Mai, Calum Bennachie, and Calogero Giametta. 2020. Community-Based Responses to Negative Health Impacts of Sexual Humanitarian Anti-Trafficking Policies and the Criminalization of Sex Work and Migration in the US'. Social Sciences 9: 1. Available online: https://www.mdpi.com/2076-0760/ 9/1/1 (accessed on 3 March 2021). [CrossRef]

Howard, Neil. 2020. What Is Exploitation Anyway? Open Democracy: Beyond Trafficking and Slavery. Available online: https: //www.opendemocracy.net/en/beyond-trafficking-and-slavery/what-exploitation-anyway/ (accessed on 3 March 2021).

Immigration Act. 2009. 2009 No51. Available online: http://www.legislation.govt.nz/act/public/2009/0051/latest/whole.html (accessed on 1 May 2021).

Jackson, Moana. 2020. Where to next? Decolonisation and stories in the land. In Imagining Decolonisation. Edited by Bianca Elkington, Moana Jackson, Rebecca Kiddle, Ocean Ripeka Mercier, Mike Ross, Jennie Smeaton and Amanda Thomas. Wellington: Bridget Williams Books.

Kempadoo, Kamala. 2001. Women of Color and the Global Sex Trade: Transnational Feminist Perspectives. Meridians 12: $28-51$. Available online: https: / / www.jstor.org/stable/40338451?seq=1 (accessed on 3 March 2021). [CrossRef]

Lam, Elene, and Annalee Lepp. 2019. Butterfly: Resisting the harms of anti-trafficking policies and fostering peer-based organising in Canada. Anti-Trafficking Review 12: 91-107. Available online: https://www.antitraffickingreview.org/index.php/atrjournal/ article/view/379 (accessed on 3 March 2021). [CrossRef]

Macioti, P.G., Eurydice Aroney, Calum Bennachie, Anne E. Fehrenbacher, Calogera Giametta, and Jennifer Musto. 2020. Framing the Mother Tac. The Gendered, Sexualised and Racialised Politics of Modern Slavery in Australia. Social Sciences 9: 192. Available online: https: / www.mdpi.com/2076-0760/9/11/192 (accessed on 18 May 2021).

Mai, Nicola. 2018. Mobile Orientations. An Intimate Autoethnography of Migration, Sex Work and Humanitarian Borders. Chicago: Chicago University Press.

Mai, Nicola, P. G. Macioti, Calum Bennachie, Anne E. Fehrenbacher, Calogera Giametta, Heidi Hoefinger, and Jennifer Musto. 2021. The Racialised Bordering Politics of Sexual Humanitarianism: Migration, Sex Work and Trafficking. Ethnic and Racial Studies. Ethnic and Racial Studies. [CrossRef]

McCann, Mitch. 2019. Revealed: Hundreds of Suspected Sex Workers Stopped at NZ Border, Newshub. June 5. Available online: https: / www.newshub.co.nz/home/new-zealand/2019/06/revealed-hundreds-of-suspected-sex-workers-stopped-atnz-border.html (accessed on 3 March 2021).

Mercier, Ocean Ripeka. 2020. What is Decolonisation? In Imagining Decolonisation. Edited by Bianca Elkington, Moana Jackson, Rebecca Kiddle, Ocean Ripeka Mercier, Mike Ross, Jennie Smeaton and Amanda Thomas. Wellington: Bridget Williams Books.

Musto, Jennifer, Anne E. Fehrenbacher, Heidi Hoefinger, Nicola Mai, P.G. Macioti, Calum Bennachie, Calogera Giametta, and Kate D'Adamo. 2021. AntiTrafficking in the Time of FOSTA/SESTA: Networked Moral Gentrification and Sexual Humanitarian Creep. Social Sciences 10: 58. Available online: https:/ /www.mdpi.com/2076-0760/10/2/58 (accessed on 3 March 2021). [CrossRef]

O'Connell Davidson, Julia. 2005. Children in the Global Sex Trade. Cambridge: Polity Press.

Prostitution Law Review Committee. 2008. Report of the Prostitution Law Review Committee on the Operation of the Prostitution Reform Act 2003. Wellington: Government Print.

Prostitution Reform Act. 2003. 2003 No28. Available online: http:/ /www.legislation.govt.nz/act/public/2003/0028/latest/whole.html (accessed on 3 March 2021).

Radio New Zealand. 2020. Alice Snedden's Bad News: Episode 1-Migrant Sex Workers. Wellington: Government Print. Available online: https: / www.youtube.com/watch?v=n67lgR2R58k (accessed on 3 March 2021).

Roguski, Michael. 2013. Occupational Health and Safety of Migrant Sex Workers in New Zealand. Wellington: Kaitiaki Research. Available online: http:/ / www.communityresearch.org.nz/research/occupational-safety-and-health-of-migrant-sex-workers-in-newzealand/ (accessed on 3 March 2021).

Segrave, Marie, Sanja Milivojevic, and Sharon Pickering. 2009. Sex Trafficking. International Context and Response. Cullompton: Willan Publishing.

Selvey, Linda A., Roanna C. Lobo, Kahlia L. McCausland, Basil Donovan, Julie Bates, and Jonathan Hallett. 2018. Challenges facing Asian sex workers in Western Australia: implications for health promotion and support services. Frontiers in Public Health 6: 171. Available online: https:/ / pubmed.ncbi.nlm.nih.gov/29951477/ (accessed on 18 May 2021). [CrossRef] [PubMed]

Tan, Lincoln. 2013. Prostitutes kept out despite visa, New Zealand Herald. June 5. Available online: https://www.nzherald.co.nz/nz/ news / article.cfm?c_id=1andobjectid=10888451 (accessed on 3 March 2021).

Tan, Lincoln. 2018a. Human Trafficking: Lured Migrant Face Dark Reality, New Zealand Herald. April 16. Available online: https:/ / www.nzherald.co.nz/nz/news/article.cfm?c_id=1andobjectid=12021043 (accessed on 18 May 2021).

Tan, Lincoln. 2018b. NZ Sex Workers Lodge Complaints over Foreign Prostitute Website Advertisements, New Zealand Herald. April 22. Available online: https://www.nzherald.co.nz/nz/news/article.cfm?c_id=1andobjectid=12037429 (accessed on 3 March 2021).

Tan, Lincoln. 2018c. Illegal Workers Access Million-Dollar Taxpayer-Funded Health Programme, New Zealand Herald. May 31. Available online: https:/ / www.nzherald.co.nz/nz/news/article.cfm?c_id=1andobjectid=12061215 (accessed on 1 May 2021).

Tichenor, Erin G. 2019. [De] Criminalization: Social Control, Agency, and Intersectionality in Auckland's Sex Industry. Thinking Gender Papers. April 1. Available online: https:/ / escholarship.org/uc/item/1nb0d1rn (accessed on 1 May 2021). 
Timmins, Michael. 2020. Settlement on Sexual Harassment Proceedings, Scoop. December 14. Available online: https://www.scoop.co. nz/stories/PO2012/S00119/settlement-on-sexual-harassment-proceedings.htm (accessed on 3 March 2021).

Ting, David. 2018. Understanding the Experiences of Migrant Asian Sex Workers in New Zealand: An Exploratory Study. Master's Thesis, Auckland University, Auckland, New Zealand. Available online: https:/ /www.nzpc.org.nz//pdfs/Ting,-D,-(2018), -Understanding-the-experiences-of-migrant-Asian-sex-workers-in-New-Zealand-An-exploratory-study.-MA-Thesis.pdf (accessed on 1 May 2021).

Trevett, Claire. 2018. Minister Tells Immigration NZ to Suspend Migrant Risk Factor Data Modelling Programme Amid Racial Profiling Claims, New Zealand Herald. April 9. Available online: https:/ /www.nzherald.co.nz/nz/minister-tells-immigration-nz-tosuspend-migrant-risk-factor-data-modelling-programme-amid-racial-profiling-claims /WVZU56CQBEUK5YZN4UJDUGL3 SA/ (accessed on 1 May 2021).

United Nations. 2018. United Nations Committee on the Convention on the Elimination of All Forms of Discrimination against Women; Concluding Observations on the Eighth Periodic Report of New Zealand, CEDAW/C/NZL/CO/8. Geneva: United Nations. Available online: http:/ / docstore.ohchr.org/SelfServices /FilesHandler.ashx?enc=6QkG1d\%2fPPRiCAqhKb7yhsqMFgv33OTgoZv7ZAgL6 thAQ9IftfPs3g9t3r4w6hFnRBqTwEr\%2biim0\%2bsAlJpAatSmEIaiBa2tDiXsJJkM5ckb8X\%2btUaeYYYiJ63zQJJg6JG (accessed on 3 March 2021). Concluding Observations on the Eighth Periodic Report of New Zealand, CEDAW/C/NZL/CO/8. 